\title{
Stability and Quality of Anthocyanin in Purple Sweet Potato Extracts
}

\author{
Chin-Chia Chen ${ }^{1}$, Chi Lin ${ }^{1}$, Min-Hung Chen ${ }^{2}$ and Po-Yuan Chiang ${ }^{1, *}$ \\ 1 Department of Food Science and Biotechnology, National Chung Hsing University, Taichung 40227, Taiwan \\ 2 Agriculture \& Food Agency Council of Agriculture Executive Yuan Marketing \& Processing Division, \\ Taipei 10050, Taiwan \\ * Correspondence: pychiang@dragon.nchu.edu.tw; Tel.: +886-4-2285-1665
}

Received: 9 August 2019; Accepted: 4 September 2019; Published: 6 September 2019

\begin{abstract}
Because of the high nutritional value of anthocyanin in purple sweet potatoes (TN57), the stability and quality of anthocyanin in purple sweet potatoes during and after the processing were investigated in this study. First of all, the extraction methods with different parameters, such as temperature, time, solid-liquid ratio, $\mathrm{pH}$ value, and solvent were employed to get better extraction efficiencies. After that, DPPH (1,1-diphenyl-2-picrylhydrazyl) and ABTS (2,2'-azino-bis (3-ethylbenz thiazoline-6-sulphonic acid) were used to evaluate the anti-oxidation ability of the extracts. Lastly, the thermal degradation kinetics and photodegradation were used to obtain important degradation factors including the content of anthocyanin residue, degradation index (DI), color parameters, reaction rate $(\mathrm{k})$, and chromatic aberration $(\Delta \mathrm{E})$. We found that the extraction condition as using $60 \%$ ethanol with $1 \%$ citric acid under $80{ }^{\circ} \mathrm{C}$ for $40 \mathrm{~min}$ was optimal for purple sweet potatoes, which obtained antioxidant capacity as $333 \mu \mathrm{M}$ TE DPPH, $376 \mu \mathrm{M} \mathrm{TE} \mathrm{ABTS}{ }^{+}$, and $593.6 \mu \mathrm{M} \mathrm{TE}$ ferric ion reducing antioxidant power (FRAP). The results indicate that the most important parameter for the stability of anthocyanin in the purple sweet potato extract (PSPAE) was the $\mathrm{pH}$ value rather than temperature. In addition, there was no significant difference in chromatic aberration between the light and dark storage conditions under $37^{\circ} \mathrm{C}$. Thus, PSPAE has the potential to be developed as health foods and drinks rich in anthocyanin.
\end{abstract}

Keywords: purple sweet potato; anthocyanin; antioxidant capability; degradation

\section{Introduction}

Sweet potatoes (Ipomoea batatas L.) are widely cultivated in tropical and subtropical areas, since it has been introduced from the South America in the early 18th century [1]. The enrichment in starch, crude protein, dietary fibers, minerals, pigments, and polyphenols makes it one of the most important root crops in agricultural production as well as a major raw supply in the food industry nowadays [2,3]. Several sweet potato cultivars, such as TN57, TN66, TN72, and TN73, have been cultivated in Taiwan. Among them, the purple sweet potato (TN73) has distinctive prunosus peel and deep purple flesh with an inviting flavor and mouth feeling $[4,5]$. Because of these advantages, the purple sweet potato is served as various dishes, nutritional brewing dry powder, stuffing, sweetmeat etc., in food processing industry, and has become a popular cultivar in Asia [6]. As a staple crop, the purple sweet potato is rich in bioactive phyto pigments and good antioxidant ability, these undoubtedly make it as the star variety of sweet potatoes $[7,8]$. The high content of anthocyanin in purple sweet potato has been verified in a previous study, which were $19.78 \mathrm{mg} / 100 \mathrm{~g}$ in water extract and $158 \mathrm{mg} / 100 \mathrm{~g}$ in acid-ethanol $(\mathrm{HCl}, 1.5 \mathrm{mM})[9,10]$, while cyanidin and peonidin are the major components of the purple sweet potato anthocyanin [11]. Comparing to other anthocyanin enrichment foods, like black hawk raspberry (315.9 mg/100 g), black waxy rice (17.89-99.53 mg/100 g), and grape (1076 mg/100 g), 
the anthocyanin content of purple sweet potato is not the best [12-14]. But the advantage of low cultivation cost, short growth periodicity, strong adaptability to different environment, and can be planted all year round, making purple sweet potato a potential raw material for producing commercial anthocyanin products. Besides the vivid colors, its excellent water solubility and biological activity, such as anti-diabetes, anti-obesity, clearance of hepatic lipid, anti-tumor, and anti-inflammation allows it to be used as health foods and in nutritional supplements [15-18].

In recent years, the global temperature has continuously risen, and the scorching heat wave increases the market demand for various drinks in tropical and subtropical areas [19]. Because of the stimulation to the mouth and the refreshing sensation to the throat, fizzy drink has become the most popular choice today. Most of the popular fizzy drinks nowadays, such as cola, pepsi, and sprite, have some unhealthy factors, like the unnatural chemical additives and high calorie, which are against the health concept of the modern society, emphasizing on low carbohydrate, usage of bioactive components, natural pigments extracts as artificial colorant substitutions $[20,21]$. The market of sparkling water or sparkling wine will grow rapidly with the widespread health concept [22-24]; hence, to improve the market acceptability, flavor, and health benefits of sparkling water, several natural components can be employed in this revolution of carbonated drinks. Because of the innate characters of anthocyanin, such as antioxidant ability, various colors, bioactivity, water soluble, anthocyanin becomes an optimal choice for the natural healthy drinks production [25-27].

Raw material characteristics and processing parameters are the major variables in the processes of agricultural products, such as thermal temperature, storage time, oxygen content, $\mathrm{pH}$ value, light, metal ion, and enzyme activity [28]. Anthocyanin pigments are unstable at high $\mathrm{pH}$ values, and may present unique colors at different $\mathrm{pH}$ such as red $(\mathrm{pH} 1)$, purple $(\mathrm{pH} 7)$, blue $(\mathrm{pH} 10)$, green $(\mathrm{pH} 11)$, and yellow ( $\mathrm{pH}$ 13). However, the yellow color indicates the formation of chalcones, which is an anthocyanin degradation product $[27,29]$. Besides, thermal temperature, continuous illumination and storage time are equally important factors in affecting the degradation and color change of anthocyanin extracts [30,31]. Regrettably, there are less studies on purple sweet potato anthocyanin extract of food grade processing and storage. In this study, the optimal extraction method of anthocyanin in the purple sweet potato is established to evaluate the potential of using the anthocyanin extracts in sparkling drinks. The anti-oxidation ability of the extracts is examined and the effects of different processing factors, such as, $\mathrm{pH}$ value, temperature, illumination, and storage time on anthocyanin content, color, and degradation kinetics are investigated.

\section{Materials and Methods}

\subsection{Materials}

Purple sweet potato (TN73) was purchased from Guarantee responsibility Qiongpu Cooperative Farm (Yunlin, Taiwan). The chemicals, 1,1-diphenyl-2-picrylhydrazyl (DPPH), 2,2'-azino-bis (3-ethylbenz thiazoline-6-sulphonic acid) (ABTS), 6-hydroxy-2,5,7,8-tetra-methylchroman-2-carboxylic acid (Trolox), and 2,4,6-Tri(2-pyridyl)-s-triazine (TPTZ) were purchased from Alfa Aesar (Haverhill, Massachusetts, America), Sigma-Aldrich (Saint Louis, Missouri, America), and Acros Organics (Geel, Belgium), respectively.

\subsection{Extraction of Anthocyanin from Purple Sweet Potato}

The fresh purple sweet potato was washed, peeled, and shredded. After freeze-drying and milling, the powder was evenly mixed and stored in an aluminum foil bag in the dark. To find out the suitable extraction method of purple sweet potato anthocyanin, both distilled water and ethanol, containing $0.1,0.5,1.0$, or $1.5 \%$ citric acid were applied as extract solution, with the solid-liquid ratio as 1:5, 1:10, or $1: 15$, at a temperature of 60,70 , or $80^{\circ} \mathrm{C}$, and extraction time as $10,20,30,40,50$, or 60 minutes under $100 \mathrm{rpm}$ of shaking. The extracts were then cooled rapidly to $4{ }^{\circ} \mathrm{C}$ and filtered to get the purple sweet potato anthocyanin extract (PSPAE), then store at $-20^{\circ} \mathrm{C}$ for following experiments. 


\subsection{Analysis of Anthocyanin Content and Degradation Index}

The method described in the previous study [32] was modified to analyze anthocyanin. The anthocyanin content was estimated based on the characterization that anthocyanin has a maximum absorption peak at $\mathrm{pH} 1$ and no absorption peak at $\mathrm{pH} 4.5$ under $525 \mathrm{~nm}$ as the following formula. The PSPAE was mixed with $25 \mathrm{mM}$ hydrochloric acid-potassium chloride buffer $(\mathrm{pH} 1)$ or $0.4 \mathrm{M}$ sodium acetate buffer ( $\mathrm{pH} 4.5$ ) for 15 minutes in the dark. Then, the optical density of the mixtures was measured at $700 \mathrm{~nm}$ and $525 \mathrm{~nm}$, and the anthocyanin content was calculated as the formula (Equations (1) and (2)). Since anthocyanin would convert into chalcone in the unstable environment, the absorbance ratio $\mathrm{A}_{420} / \mathrm{A}_{525}$ of anthocyanin was also measured to be used as the degradation index (DI). The higher the ratio value, more critical the degradation of anthocyanin was.

$$
\begin{aligned}
& \mathrm{A}=\left(\mathrm{A}_{\lambda \text { vis-max }}-\mathrm{A}_{700}\right) \times \mathrm{pH} 1.0-\left(\mathrm{A}_{\lambda \text { vis-max }}-\mathrm{A}_{700}\right) \times \mathrm{pH} 4.5 \\
& \text { Anthocyanin content }(\mathrm{mg} / \mathrm{L})=(\mathrm{A} \times \mathrm{MW} \times \mathrm{DF} \times 1000) /(\varepsilon \times 1),
\end{aligned}
$$

MW: anthocyanin molecular weight was calculated as cyanidin-3-glucoside (449.2), DF: dilution factor, E: molar absorption coefficient $(\varepsilon)$ was calculated as cyanidin-3-glucoside (26900), 1: diameter of the quartz cuvette $(\mathrm{cm})$.

\subsection{Antioxidant Activity}

According to the DPPH method described previously [33], the PSPAE was mixed with $0.5 \mathrm{mM}$ 1,1-diphenyl-2-picrylhydrazyl (DPPH) at the volume ratio of 1:10, and then stood at room temperature in the dark for 30 minutes. The absorbance value was measured by spectrophotometer U-2800A (Hitachi, Tokyo, Japan) at $517 \mathrm{~nm}$ after the reaction. DPPH radical scavenging capacity was calculated by the following formula (Equation (3)).

The ABTS reagent was prepared according to the ABTS method described previously [34]. A total of $5 \mathrm{~mL}$ ABTS was mixed with $88 \mu \mathrm{L} 140 \mathrm{mM}$ potassium persulfate and incubated at room temperature overnight in the dark. The solution was then adjusted to an absorbance of 0.7 at $734 \mathrm{~nm}$. The PSPAE was mixed with the ABTS reagent at the volume ratio 1:10, incubated at room temperature in the dark for 30 minutes. After the reaction, absorbance value was measured by spectrophotometer at $734 \mathrm{~nm}$. ABTS radical scavenging capacity was calculated by the following formula (Equation (4)).

The reagent for ferric ion reducing antioxidant power (FRAP) assay was freshly prepared by mixing $10 \mathrm{mM}$ TPTZ, $12 \mathrm{mM}$ ferric chloride, and $0.3 \mathrm{M}$ sodium acetate (pH 3.6) at 1:1:10 volume ratios. The assay was performed by mixing PSPAE and FRAP reagent at the volume ratio of 1:20 and incubated in the dark for 15 minutes. After the reaction, absorbance value was measured by a spectrophotometer at $593 \mathrm{~nm}$.

$$
\begin{aligned}
& \text { DPPH Radical scavenging capacity }(\%)=(A \mathrm{c}-A \mathrm{~s}) / A \mathrm{c} \times 100, \\
& \text { ABTS Radical scavenging capacity }(\%)=(A \mathrm{c}-A \mathrm{~s}) / A \mathrm{c} \times 100,
\end{aligned}
$$

Ac: absorbance of control, As: absorbance of samples.

\subsection{Color Change Measurement}

The color change of PSPAE was measured by the color meter NE-4000 (Nippon Denshku Industries Co, Ltd., Tokyo, Japan) with a $30 \psi$ aperture. The color was detected by the transmittance method, based on the calibration standard plate (0-cal plate and $H$. whiteness plate, $X=92.81, Y=94.83$, $Z=11.71)$, and the color difference $(\Delta \mathrm{E})$ was calculated by the following formula. The parameters were as follows: lightness $(L)$ with a scale $0-100$, where black $=0$ and white $=100$; symbol " $a$ " means redness 
$(+)$ and greenness (-); symbol " $b$ " means yellowness $(+)$ and blueness $(-) ; L_{0}, a_{0}$, and $b_{0}$ represent colors of another sample which was used for comparison.

$$
\Delta \mathrm{E}=\sqrt{\left(L-L_{0}\right)^{2}+\left(a-a_{0}\right)^{2}+\left(b-b_{0}\right)^{2}}
$$

\subsection{Thermal Degradation Kinetics}

PSPAE was mixed with $0.2 \mathrm{M}$ sodium phosphate dibasic buffer at ratio 1:4 $(v / v)$. The solution was adjusted to $\mathrm{pH} 1,3,5,7$ or 9 with hydrochloric acid, heated to 60,70 , or $80^{\circ} \mathrm{C}$ for $12,24,36$, or $48 \mathrm{~h}$ and then cooled rapidly for anthocyanin content analysis. According to Mercali et al. (2013), anthocyanin degradation follows the first-order reaction, and the reaction rate constants $(k)$, half-lives $\left(T_{1 / 2}\right)$, and energy activation $(E a)$ can be calculated by the following equations.

$$
\begin{gathered}
C \mathrm{t}=C_{0} \exp (-K \times t) \\
T_{1 / 2}=\ln (2) / K \\
\ln k=\ln A-E \mathrm{a} / R T,
\end{gathered}
$$

$\mathrm{C}_{0}$ : initial anthocyanin content, $\mathrm{Ct}$ : anthocyanin content at a certain point in time, $K$ : reaction rate (hours ${ }^{-1}$ ), $T$ : heating time (hours), $T_{1 / 2}$ : the time of $50 \%$ anthocyanin degradation during the heat treatment, $k\left(\right.$ hour $\left.^{-1}\right)$ : degradation constant at temperature $T$, $R$ : ideal gas constant $\left(8.314 \times 10^{-3} \mathrm{~kJ}\right.$ $\left.\mathrm{mol}^{-1} \mathrm{~K}^{-1}\right)$, A (hour $\left.{ }^{-1}\right)$ : Arrhenith constant, $T$ : absolute temperature $\left({ }^{\circ} \mathrm{K}\right)$.

\subsection{Storage Test of PSPAE}

PSPAE were settled under $4,25,37$, and $55{ }^{\circ} \mathrm{C}$ in dark or being illuminated to mimic the various storage situations after processing. The anthocyanin content, color appearance and degradation index were measured at the storage date of $0,3,6,9,12$, and 15 days.

\subsection{Statistical Analysis}

Results were expressed as the mean values \pm standard deviation. Data were analyzed by analysis of variance (ANOVA) and Duncan's multiple range test (DMRT) with the significance defined at $p<0.05$. All statistical analyses were performed by statistical analysis system (SAS, 8.01 TS Level 01M0, Institute Inc., Cary, North Carolina, America).

\section{Results and Discussion}

\subsection{Extraction Efficiency of Purple Sweet Potato Anthocyanin}

Because of the good water solubility of anthocyanin, the purple sweet potato was extracted with water at first, with $1: 15$ solid-liquid ratio under $70{ }^{\circ} \mathrm{C}$ for $30 \mathrm{~min}$. After that, the extracts were subjected to the spectral scanning from 400 to $700 \mathrm{~nm}$ (Figure 1A). In Figure 1A,B, the spectrum pattern and color changes in different $\mathrm{pH}$ values present a consistent pattern with other anthocyanin research $[35,36]$. However, the extraction efficiency of anthocyanin in purple sweet potato by water was only about $17.06 \mathrm{mg} / 100 \mathrm{~g}$ (Figure $2 \mathrm{~A}$ ), which is relatively low compared with previous results, such as $65 \mathrm{mg} / 100 \mathrm{~g}$ in Heinonen et al. [37], $83 \mathrm{mg} / 100 \mathrm{~g}$ in Huang et al. [38] and $158 \mathrm{mg} / 100 \mathrm{~g}$ in Fan et al. [10]. These low extract efficiency may be because the tissue of purple sweet potato cannot be effectively destroyed and penetrated by water. Considering that alcohol and citric acid can significantly improve the lysis ability of extraction solvent on vacuole membrane, enhance the osmosis efficiency, and make anthocyanin into a stable form of flavylium ion $[8,39,40]$, different solvents were being employed for extraction test, including water/ethanol, water/citric acid, and water/ethanol/citric acid. As shown in Figure 2A-C, taking into account the cost and limitation of extract efficiency of anthocyanin extraction, $60 \%$ ethanol with $1 \%$ citric acid is considered the most suitable method, which gives the extract content 
of $83 \mathrm{mg} / 100 \mathrm{~g}$. To further increase the anthocyanin content of extracts, the extraction time, solid-liquid ratio and temperature were readjusted. As shown in Figure 2D,E, all results under different conditions showed that $40 \mathrm{~min}$ heating was the first to achieve maximum efficiency. Besides, the highest extract content of anthocyanin has been presented as $93.64 \mathrm{mg} / 100 \mathrm{~g}$ at the $1: 15$ solid-liquid ratio, $80{ }^{\circ} \mathrm{C}$ heating, and using $60 \%$ ethanol and $1 \%$ citric acid as the extract solution (Figure 2E).

\subsection{Antioxidant Capacity}

In the past decade, anthocyanin has been considered as an excellent scavenger for oxygen radicals with numerous health benefits, such as visual improvement, platelet aggregation inhibition, carcinogenesis inhibition [41-43]. Anthocyanin is formed basically by C6-C3-C6 carbon skeletons, and the radical scavenging activity of anthocyanin is dependent on the hydroxylation level on the R1 and R3 position of B-ring [44]. Several in vitro antioxidant assays such as those using substrates DPPH and ABTS and the FRAP radical scavenging activity assay (Figure 1) were performed in this study to evaluate the potential of PSPAE in health food production.

A

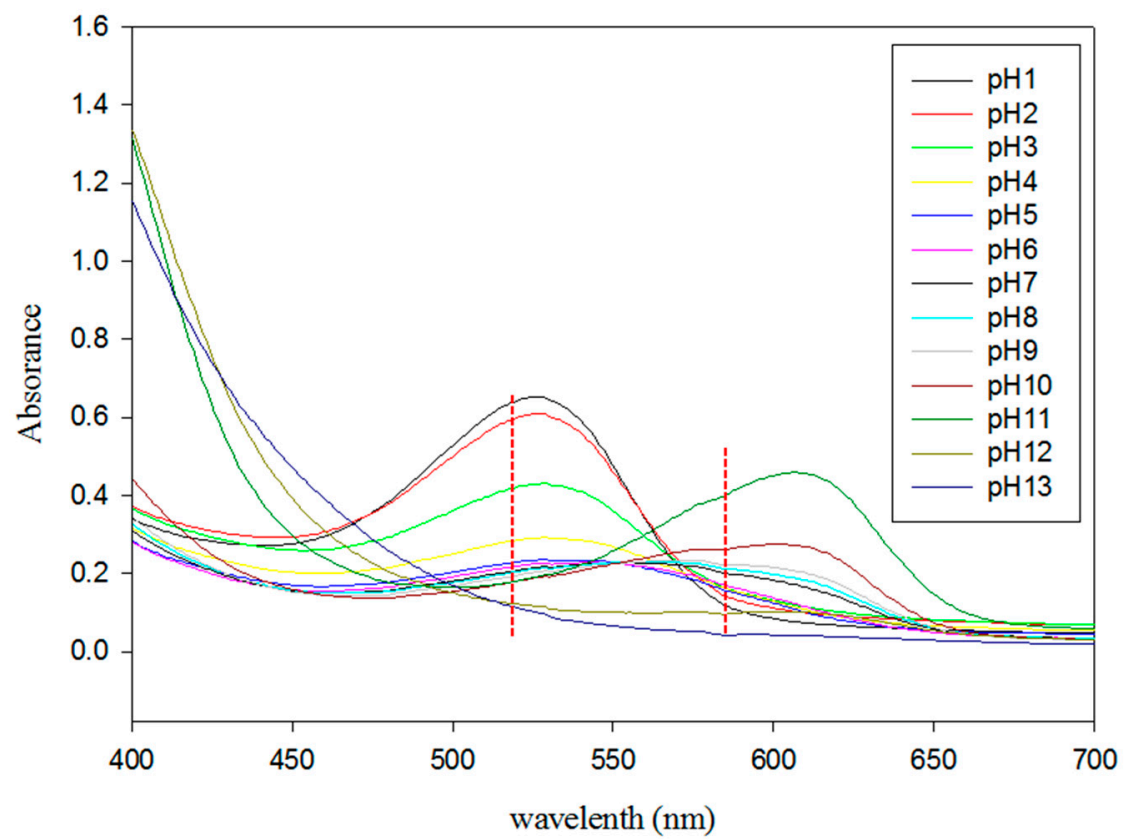

B wavelenth $(\mathrm{nm})$

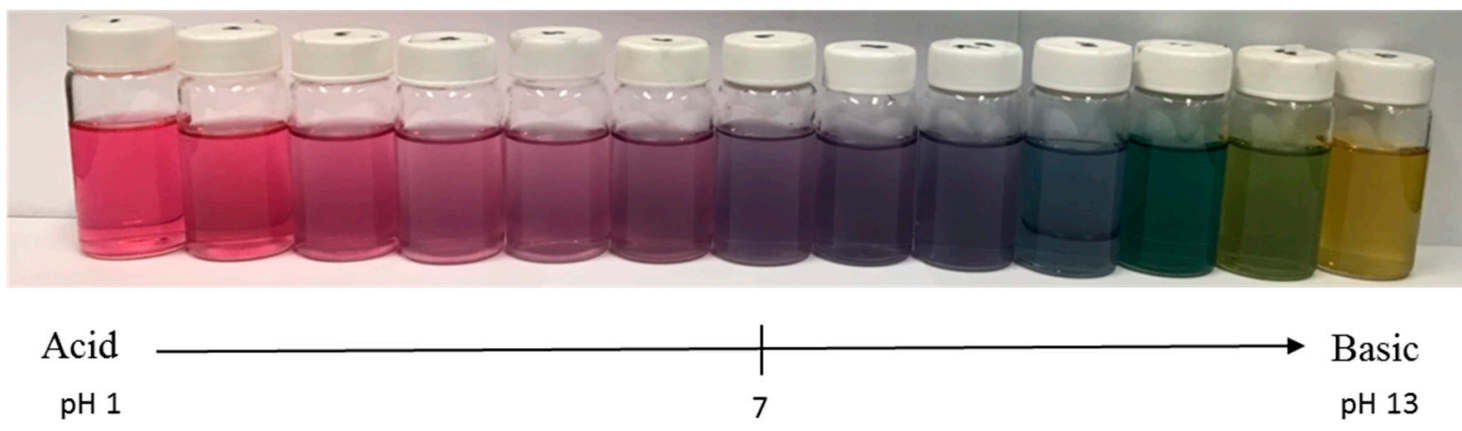

Figure 1. UV spectrum (A) and color appearance (B) of purple sweet potato extract (PSPAE) at pH 1-13. 

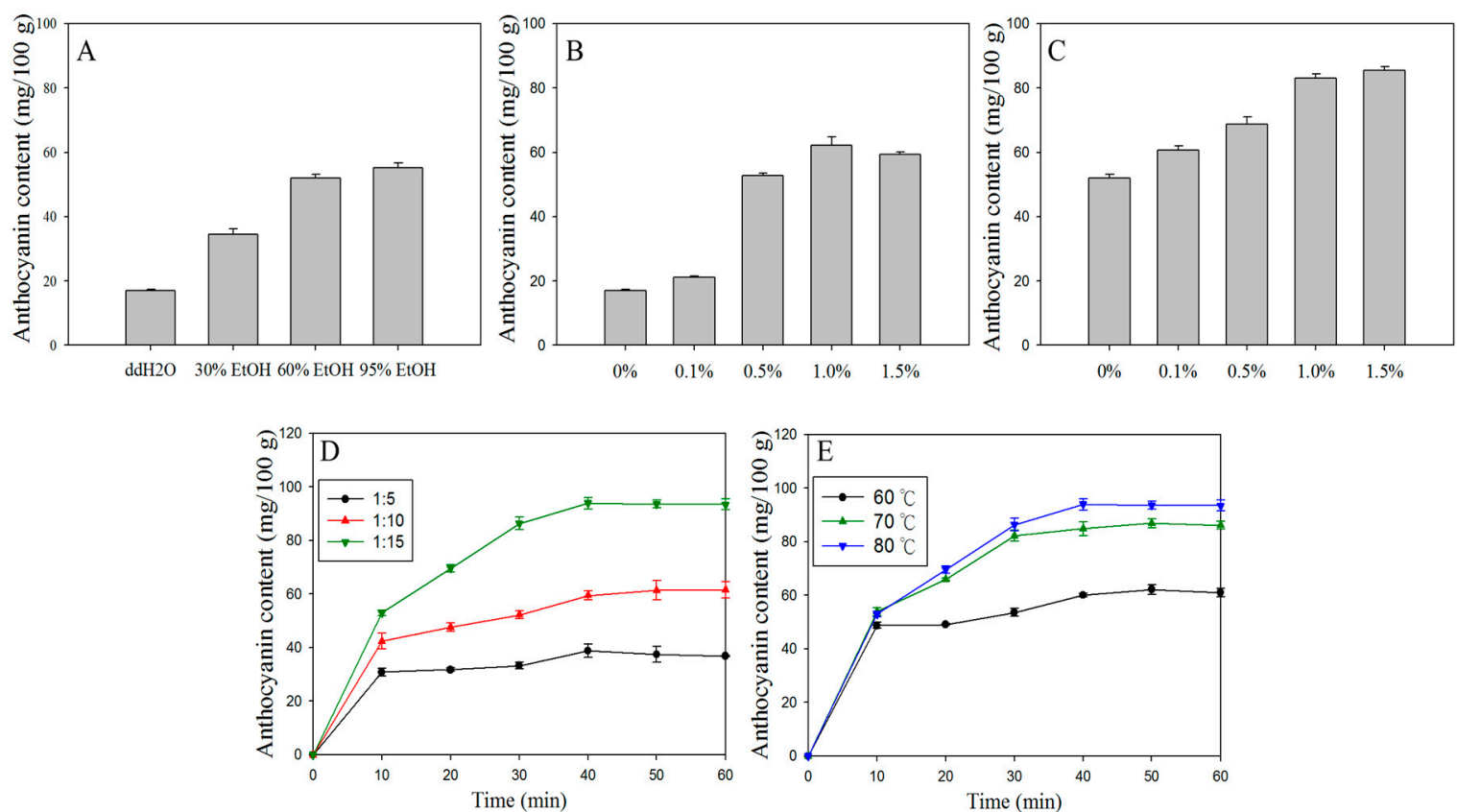

Figure 2. Effects of various extraction factors on the total anthocyanin content in PSPAE. (A) ratio of ethanol and water, (B) citric acid with water, (C) citric acid with 60\% ethanol, (D) solid-liquid ratio,

(E) extraction temperature.

The free radical scavenging activity of PSPAE increased with the increase of anthocyanin concentration in the DPPH assay and reached $80 \%$ as the anthocyanin content was $40 \mathrm{mg} / \mathrm{mL}$. There was still $31 \%$ scavenging capacity at the anthocyanin concentration of $10 \mathrm{mg} / \mathrm{mL}$, presenting $\mathrm{IC}_{50}$ at $13.16 \mathrm{mg} / \mathrm{mL}$ (195.72 $\mu \mathrm{M}$ equivalent Trolox) (Figure 3A). Because the hydrophobicity of DPPH may influence the activity of hydrophilic compound, the water soluble $\mathrm{ABTS}^{+}$has also been used to achieve more comprehensive understanding. The $\mathrm{ABTS}^{+}$free radical scavenging activity of PSPAE could reach $90 \%$ as the anthocyanin content was $30 \mathrm{mg} / \mathrm{mL}$, and present $\mathrm{IC}_{50}$ at $7.23 \mathrm{mg} / \mathrm{mL}(193.84 \mu \mathrm{M}$ equivalent Trolox (TE) (Figure 3B). Different from DPPH and $\mathrm{ABTS}^{+}$which use the anti-oxide compounds to remove specific free radicals, FRAP is based on the integrated reducing ability of the sample as an evaluation of antioxidant ability [45]. PSPAE reached upper limit in reducing $\mathrm{Fe}^{3+}$ to $\mathrm{Fe}^{2+}$ at $40 \mathrm{mg} / \mathrm{mL}$, corresponding to $593.6 \mu \mathrm{M}$ TE FRAP (Figure 3C). Comparing to the limit ability of PSPAE in scavenging DPPH and $\mathrm{ABTS}^{+}$, which is about $333 \mu \mathrm{M}$ TE DPPH and $376 \mu \mathrm{M} \mathrm{TE} \mathrm{ABTS}^{+}$, PSPAE not only was rich in antioxidant compounds, but also contained many reduction state compounds, which can assist in stability and quality during preservation and processing. Among several anthocyanin enrichment foods presenting various antioxidant abilities, such as Korean colored rice $(246.9 \mu \mathrm{M}$ TE in DPPH, $19.9 \mu \mathrm{M}$ TE in $\left.\mathrm{ABTS}^{+}\right)$, Italian sour cherry $(115 \mu \mathrm{M}$ TE in DPPH), and wild grape (30.9 $\mu \mathrm{M}$ TE in FRAP) [46-48]. PSPAE has a comparable outstanding capability in free radical scavenging. Besides, it is interesting that even if raspberry has higher content of anthocyanin mentioned above, it presents lower radical scavenging ability as $92.6 \mu \mathrm{M} \mathrm{TE}$ and $94.4 \mu \mathrm{M}$ TE in DPPH and ABTS ${ }^{+}$respectively [49]. This indicates that the two major type of anthocyanin in PSPAE are more powerful or there are many other antioxidative compounds in the PSPAE. 

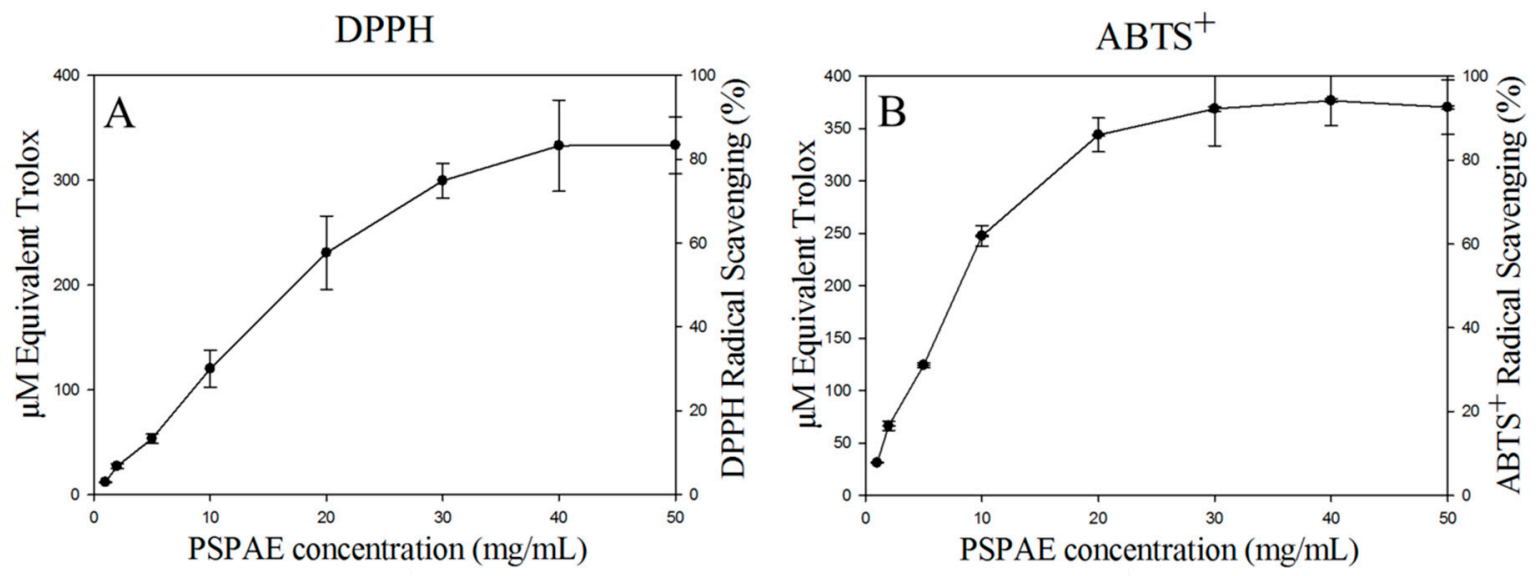

FRAP

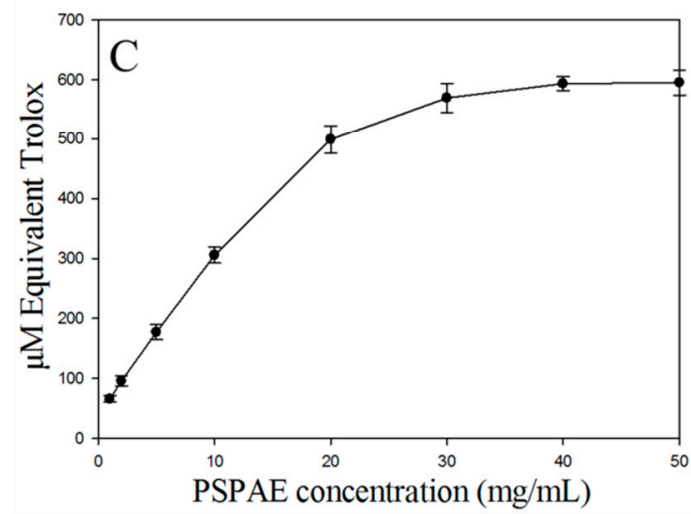

Figure 3. Antioxidant activity of PSPAE. (A) DPPH (1,1-diphenyl-2-picrylhydrazyl) assay, (B) ABTS (2,2'-azino-bis (3-ethylbenz thiazoline-6-sulphonic acid)) assay, (C) FRAP (ferric ion reducing antioxidant power) assay.

\subsection{Thermal Degradation Kinetics}

The characteristic of raw material, $\mathrm{pH}$ value of environment, and heating temperature of sterilization are factors that could accelerate the degradation of many natural plant pigments during processing, so to examine the degradation attribute of PSPAEs is vital [30]. In this study, acid alcohol aqueous solution was used as the extraction solution; besides, the low $\mathrm{pH}$ value $(\mathrm{pH}<4.6)$ and boiling point was suitable for pasteurization. Thus, the content change and degradation index (DI) of anthocyanin during heating temperature 60,70 , and $80^{\circ} \mathrm{C}$ with different $\mathrm{pH}$ value were investigated. The increase of degradation index of anthocyanin was proportional to the heating temperature and time; nonetheless, it is worth noting that the degradation patterns at the lower and the higher $\mathrm{pH}$ values were different (Figure $4 \mathrm{~A}-\mathrm{C}$ ). As shown in Figure $2 \mathrm{C}$, after heating at $80^{\circ} \mathrm{C}$ for $48 \mathrm{~h}$, anthocyanin degradation index slightly went up to 0.68 from 0.5 at $\mathrm{pH} 1$, but jumped to 1.4 from 0.65 at $\mathrm{pH} 9$. Even we knew that the degradation speed of anthocyanin accelerates by the heating temperature and time [50]; anthocyanin degradation index under $60^{\circ} \mathrm{C}$ heating for $48 \mathrm{~h}$ still went up to 0.99 at $\mathrm{pH} 9$, which is much more than the result at $\mathrm{pH} 1$ under $80^{\circ} \mathrm{C}$ heating (Figure $4 \mathrm{~A}, \mathrm{C}$ ). Besides, the degradation of anthocyanin followed the first-order reaction, and had the same results as the degradation index of anthocyanin (Figure 4D-F). As shown in Table 1, the reaction rate constant (k) was $6.21 \times 10^{-3}$ in $60^{\circ} \mathrm{C}$ and went up to $8.72 \times 10^{-3}$ under $80^{\circ} \mathrm{C}$ at $\mathrm{pH} 1$. In addition, the reaction rate also accelerated with the increase of $\mathrm{pH}$ value; for example, the reaction rate at $\mathrm{pH} 1$ was about 2.7 times of that at $\mathrm{pH} 9$ at $80^{\circ} \mathrm{C}$, indicating that the high $\mathrm{pH}$ value $(\mathrm{pH} 9)$ and high temperature $\left(80^{\circ} \mathrm{C}\right)$ accelerates the degradation rate of anthocyanin, as the reaction rate constant at $\mathrm{pH} 9$ was $2.38 \times 10^{-2}$ in $80^{\circ} \mathrm{C}$.

The reaction rate constant, half-life $\left(\mathrm{T}_{1 / 2}\right)$ and activation energy $(E \mathrm{a})$ of the degradation process of anthocyanin are useful to evaluate the quality of PSPAEs. It is obvious that the half-life decreased 
as the temperature and $\mathrm{pH}$ rises; especially under the $80{ }^{\circ} \mathrm{C}$ heat-treated process, $\mathrm{T}_{1 / 2}$ at $\mathrm{pH} 1$ is $2.7 \times$ longer than that at $\mathrm{pH} 9$ (Table 1). The activation energy was calculated by Arrhenius equation to present the energy needed for the change of anthocyanin extracts. The values of Ea were not different between $\mathrm{pH} 1$ and $\mathrm{pH} 3(59.82$ and $59.55 \mathrm{~kJ} / \mathrm{mol}$ ), but dropped drastically to $26.13 \mathrm{~kJ} / \mathrm{mol}$ at pH 9 (Table 1). The degradation trend of PSPAEs was similar to other agricultural produce; for example, the previous research on blueberry juice indicated that $T_{1 / 2}$ of anthocyanin was $180.5 \mathrm{~h}$ and $5.1 \mathrm{~h}$ at $50{ }^{\circ} \mathrm{C}$ and $80{ }^{\circ} \mathrm{C}$ respectively [51]. From multiple perspectives, the preservation of anthocyanin is highly dependent on $\mathrm{pH}$ value. Concluded from different research which associated with various natural agricultural foods processing product, anthocyanin is recommend to be preserved under $\mathrm{pH}$ 3. This phenomenon may relate to the production of hydrogen peroxide, which could induce and accelerate the degradation anthocyanin [52]. In addition, some of the natural organic acid in the foods, like ascorbic acid, could protect anthocyanin from degradation by hydrogen peroxide [53].
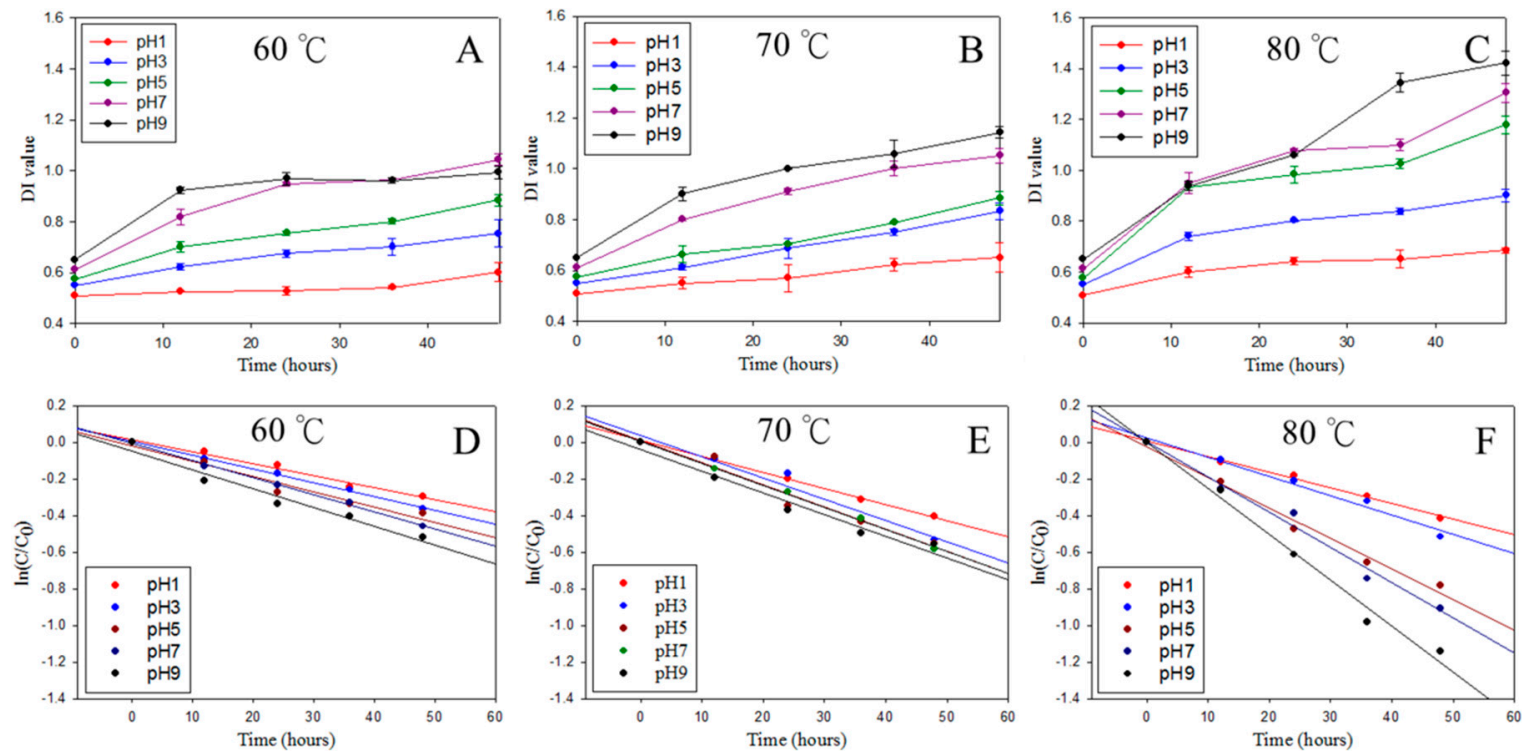

Figure 4. Thermal degradation kinetics of PSPAE in different $\mathrm{pH}$. (A-C) Degradation index, (D-F) total anthocyanin content.

Table 1. Effects of thermal and $\mathrm{pH}$ on the $K, T_{1 / 2}$, and Ea values within anthocyanin degradation.

\begin{tabular}{|c|c|c|c|c|c|}
\hline $\mathrm{pH}$ & Temperature $\left({ }^{\circ} \mathrm{C}\right)$ & $k\left(\right.$ hour $\left.^{-1}\right)$ & $T_{1 / 2}($ hour $)$ & $E a(\mathrm{~kJ} / \mathrm{mol})$ & Arrhenius Equation \\
\hline \multirow{3}{*}{1} & 60 & $6.21 \times 10^{-3}$ & 111.66 & \multirow{3}{*}{59.82} & \multirow{3}{*}{$y=-2010.7 x+1.0002$} \\
\hline & 70 & $8.47 \times 10^{-3}$ & 81.84 & & \\
\hline & 80 & $8.72 \times 10^{-3}$ & 79.52 & & \\
\hline \multirow{3}{*}{3} & 60 & $7.64 \times 10^{-3}$ & 90.7 & \multirow{3}{*}{59.55} & \multirow{3}{*}{$y=-2019.7 x+1.1764$} \\
\hline & 70 & $8.72 \times 10^{-3}$ & 83.23 & & \\
\hline & 80 & $1.08 \times 10^{-2}$ & 64.26 & & \\
\hline \multirow{3}{*}{5} & 60 & $8.12 \times 10^{-3}$ & 85.41 & \multirow{3}{*}{29.38} & \multirow{3}{*}{$y=-4094 x+7.4764$} \\
\hline & 70 & $1.15 \times 10^{-2}$ & 60.39 & & \\
\hline & 80 & $1.63 \times 10^{-2}$ & 42.55 & & \\
\hline \multirow{3}{*}{7} & 60 & $9.59 \times 10^{-3}$ & 72.25 & \multirow{3}{*}{30.26} & \multirow{3}{*}{$y=-3975.1 x+7.2548$} \\
\hline & 70 & $1.22 \times 10^{-2}$ & 56.92 & & \\
\hline & 80 & $1.89 \times 10^{-2}$ & 36.66 & & \\
\hline \multirow{3}{*}{9} & 60 & $1.08 \times 10^{-2}$ & 64.14 & \multirow{3}{*}{26.13} & \multirow{3}{*}{$y=-4603.6 x+9.1887$} \\
\hline & 70 & $1.16 \times 10^{-2}$ & 59.7 & & \\
\hline & 80 & $2.38 \times 10^{-2}$ & 29.12 & & \\
\hline
\end{tabular}




\subsection{Storage Test of Photodegradation}

The light and temperature in the storage room are often the key factors for the shelf-life of beverages. Even if the food is not spoiled, the degradation of the bioactive ingredients and the color appearance changes of the products still directly affect the consumption perception. It has been reported that anthocyanin converts to chalcones via an intermediate product in which $C 4$ hydroxyl group ring is cleaved during illumination, and further oxidized to some lysate with time elapsing, such as 2,4,6-trihydroxybenzaldehyde, which causes anthocyanin degradation as well as discoloration [54,55]. Therefore, four storage temperatures, $4{ }^{\circ} \mathrm{C}, 25^{\circ} \mathrm{C}, 37^{\circ} \mathrm{C}$, and $55^{\circ} \mathrm{C}$, that reflect the condition of shelf refrigerator, indoor store, outdoor street vendor, and inner car under sun, respectively, were tested in this study. Some interesting results were observed after 15 days of storage testing. As shown in Figure 5 and Table 2, although the anthocyanin content of purple sweet potato was decreased by the time flows, over $80 \%$ anthocyanin and acceptable color change $(\Delta \mathrm{E}=20.11 \pm 0.70)$ were preserved after 15 days storage in $4{ }^{\circ} \mathrm{C}$ dark environment. Storage at $4{ }^{\circ} \mathrm{C}$ and $25^{\circ} \mathrm{C}$, regardless of light or dark environment, did not result in significant change in color appearance and the change of anthocyanin content was less than $5 \%$; in contrast, the color appearance and anthocyanin content were changed significantly at $37^{\circ} \mathrm{C}$ and $55{ }^{\circ} \mathrm{C}$ (Figure 5). According to the results of chromatic aberration $(\Delta \mathrm{E})$, degradation index (DI), and anthocyanin content, it is suitable to store PSPAE with transparent bottles in the shelf refrigerator or indoor store. Not only the bright natural color gave it a higher commodity value, but the stability of anthocyanin also showed high potential compared to others researches. Preservation of anthocyanin in different edible solutions and extracts has been reported in many previous studies. For example, $40 \%$ of roselle anthocyanin was kept in water extracts after 15 days storage in dark, under $37^{\circ} \mathrm{C}[56]$, the $\Delta \mathrm{E}$ of anthocyanin in bayberry wine rose up to 7.5 after 15 days storage under $25^{\circ} \mathrm{C}$ in dark [57]; 70\% anthocyanin in grape-pomace extracts was kept in 70\% ethanol with $0.1 \%$ hydrochloric acid after 15 days storage under $4{ }^{\circ} \mathrm{C}$ in dark [58]. These diverse results are probably caused by the content of reduction state compounds in different extract materials, and the different concentrations of anthocyanin are due to the different extraction efficiencies.
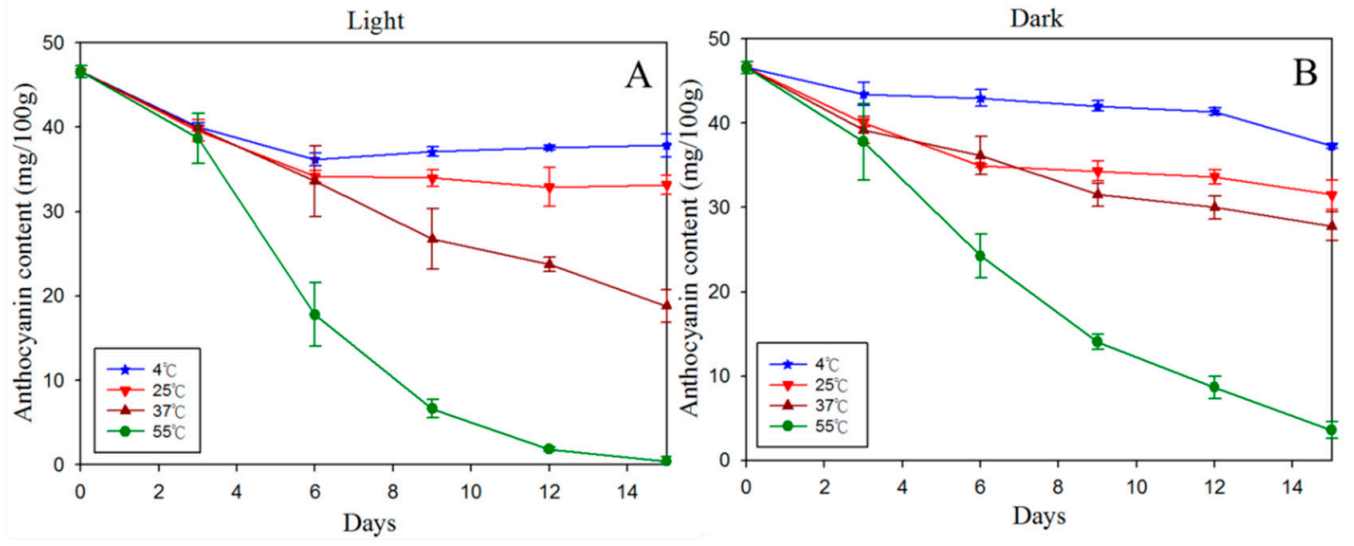

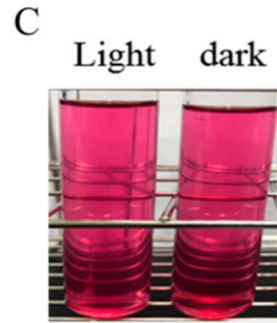

Control

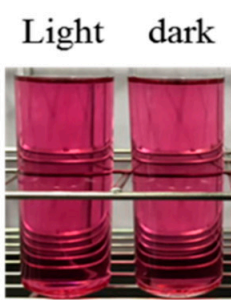

$4^{\circ} \mathrm{C}$

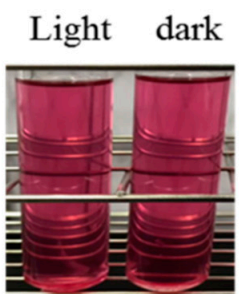

$25^{\circ} \mathrm{C}$

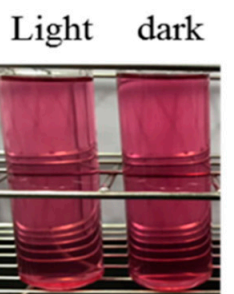

$37^{\circ} \mathrm{C}$
Light dark

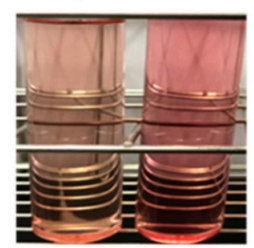

$55^{\circ} \mathrm{C}$

Figure 5. The change of anthocyanin content and appearance during different storage conditions. (A) Settled in transparent glass bottle under illumination; (B) settled in transparent glass bottle but protected from light; (C) appearance changes of PSPAE after 15 days storage. 
Table 2. Color change and degradation index within storage test.

\begin{tabular}{|c|c|c|c|c|c|}
\hline \multirow{2}{*}{ Storage Temperature } & & \multicolumn{2}{|c|}{ Light } & \multicolumn{2}{|c|}{ Dark } \\
\hline & & 6 Days & 15 Days & 6 Days & 15 Days \\
\hline \multirow{5}{*}{$4{ }^{\circ} \mathrm{C}$} & $\mathrm{L}$ & $42.68 \pm 1.07 \mathrm{dC}$ & $60.38 \pm 0.87 \mathrm{cB}$ & $43.87 \pm 0.38 \mathrm{dC}$ & $63.24 \pm 0.95^{\mathrm{bA}}$ \\
\hline & a & $44.23 \pm 0.47^{\mathrm{aC}}$ & $41.74 \pm 0.62 \mathrm{aD}$ & $55.14 \pm 2.07^{\mathrm{aA}}$ & $47.82 \pm 1.03^{\mathrm{aB}}$ \\
\hline & $\mathrm{b}$ & $10.85 \pm 0.62^{\mathrm{aA}}$ & $1.72 \pm 0.38^{\mathrm{cB}}$ & $11.03 \pm 0.82^{\mathrm{aA}}$ & $1.76 \pm 0.31^{\mathrm{dB}}$ \\
\hline & $\Delta \mathrm{E}$ & $6.90 \pm 1.16^{\mathrm{cA}}$ & $6.11 \pm 0.42^{\mathrm{cA}}$ & $6.05 \pm 0.86^{\mathrm{cA}}$ & $6.20 \pm 1.26^{\mathrm{dA}}$ \\
\hline & DI & $0.32 \pm 0.01^{\mathrm{aC}}$ & $0.34 \pm 0.01^{\mathrm{aB}}$ & $0.36 \pm 0.01^{\mathrm{aA}}$ & $0.35 \pm 0.01^{\mathrm{aB}}$ \\
\hline \multirow{5}{*}{$25^{\circ} \mathrm{C}$} & $\mathrm{L}$ & $53.80 \pm 0.49 \mathrm{cB}$ & $55.84 \pm 1.62 \mathrm{dAB}$ & $53.94 \pm 0.80 \mathrm{cB}$ & $56.47 \pm 1.10^{\mathrm{cA}}$ \\
\hline & a & $43.37 \pm 1.17 \mathrm{aB}$ & $39.65 \pm 0.65^{b C}$ & $48.91 \pm 0.92 \mathrm{bA}$ & $42.84 \pm 1.50 \mathrm{bB}$ \\
\hline & $\mathrm{b}$ & $7.74 \pm 0.53 \mathrm{bA}$ & $7.71 \pm 0.42^{\mathrm{bA}}$ & $7.29 \pm 0.39 \mathrm{bA}$ & $6.49 \pm 0.44 \mathrm{bB}$ \\
\hline & $\Delta \mathrm{E}$ & $7.98 \pm 0.85^{\mathrm{cA}}$ & $7.67 \pm 1.33 \mathrm{cA}$ & $7.28 \pm 0.93 \mathrm{cA}$ & $9.93 \pm 1.65^{\mathrm{cA}}$ \\
\hline & DI & $0.63 \pm 0.01 \mathrm{cA}$ & $0.58 \pm 0.02 \mathrm{bB}$ & $0.51 \pm 0.02^{\mathrm{bC}}$ & $0.58 \pm 0.05^{b B C}$ \\
\hline \multirow{5}{*}{$37^{\circ} \mathrm{C}$} & $\mathrm{L}$ & $61.37 \pm 1.98^{\mathrm{bB}}$ & $66.80 \pm 1.00^{\mathrm{bA}}$ & $61.37 \pm 1.99 \mathrm{bB}$ & $64.52 \pm 1.06^{\mathrm{bA}}$ \\
\hline & a & $43.75 \pm 1.08^{\mathrm{aB}}$ & $32.43 \pm 1.40^{\mathrm{cC}}$ & $46.32 \pm 0.93 \mathrm{cA}$ & $41.88 \pm 1.65^{b B}$ \\
\hline & $\mathrm{b}$ & $4.92 \pm 0.25^{\mathrm{cB}}$ & $7.45 \pm 0.48^{\mathrm{bA}}$ & $4.37 \pm 0.65^{\mathrm{cB}}$ & $5.09 \pm 0.26^{\mathrm{cB}}$ \\
\hline & $\Delta \mathrm{E}$ & $14.91 \pm 1.33^{\mathrm{bB}}$ & $18.79 \pm 1.13^{\mathrm{bA}}$ & $16.11 \pm 1.42^{b B}$ & $16.97 \pm 1.38^{\mathrm{bA}}$ \\
\hline & DI & $0.56 \pm 0.02^{b C}$ & $0.79 \pm 0.01^{\mathrm{cA}}$ & $0.56 \pm 0.01 \mathrm{cC}$ & $0.69 \pm 0.03^{\mathrm{cB}}$ \\
\hline \multirow{5}{*}{$55^{\circ} \mathrm{C}$} & $\mathrm{L}$ & $73.88 \pm 0.75^{\mathrm{aC}}$ & $87.98 \pm 0.88^{\mathrm{aA}}$ & $72.04 \pm 1.39 \mathrm{aC}$ & $82.15 \pm 1.31^{\mathrm{aB}}$ \\
\hline & a & $32.38 \pm 0.93^{b B}$ & $4.60 \pm 0.44^{\mathrm{dD}}$ & $38.72 \pm 1.03 \mathrm{dA}$ & $14.57 \pm 0.58^{c C}$ \\
\hline & $\mathrm{b}$ & $4.81 \pm 0.30^{c C}$ & $15.51 \pm 0.46^{\mathrm{aA}}$ & $4.20 \pm 0.55^{\mathrm{cC}}$ & $13.05 \pm 0.35^{\mathrm{aB}}$ \\
\hline & $\Delta \mathrm{E}$ & $26.03 \pm 0.55^{\mathrm{aC}}$ & $51.31 \pm 0.89^{\mathrm{aA}}$ & $23.89 \pm 1.26^{\mathrm{aD}}$ & $40.43 \pm 1.20^{a B}$ \\
\hline & DI & $0.73 \pm 0.05^{\mathrm{dC}}$ & $1.96 \pm 0.06^{\mathrm{dA}}$ & $0.69 \pm 0.03^{\mathrm{dD}}$ & $1.45 \pm 0.04^{\mathrm{dB}}$ \\
\hline
\end{tabular}

\footnotetext{
${ }^{1} \mathrm{~L}$ for the lightness from black (0) to white (100), a for the colors from green (-) to red (+), and $\mathrm{b}$ for the colors from blue $(-)$ to yellow $(+)$, total color difference $(\Delta \mathrm{E})$, and degradation index (DI). ${ }^{2} \mathrm{~A}-\mathrm{D}$ with the same letter means no significantly different in the row, a-d with the same letter means no significantly different in the column as each factor $(p<0.05)$.
}

\section{Conclusions}

In this study, the optimal extraction condition to obtain PSPAE, in terms of the anthocyanin content, was set up. The anti-oxidation activity, thermal degradation, and photo degradation of PSPAE were examined, in response to processing and storage conditions such as $\mathrm{pH}$ value, temperature, solvent, and time, by measuring anthocyanin content, degradation index (DI), chromatic aberration $(\Delta \mathrm{E}), \mathrm{T}_{1 / 2}$, and reaction rate constant $(k)$. The $\mathrm{pH}$ value is a more important factor during storage of PSPAE than temperature and illumination conditions. No significant difference in color appearance was observed between PSPAE samples stored in dark and light under $37^{\circ} \mathrm{C}$. These features make PSPAE worth being developed as anthocyanin-rich health foods and drinks.

Author Contributions: Conceptualization, P.-Y.C.; data curation, C.L.; formal analysis, C.-C.C.; project administration, M.-H.C.; supervision, P.-Y.C.; validation, C.-C.C.; writing-original draft, C.L.

Funding: This study was supported by council of agriculture under project 108AS-1.2.1-FD-Z2.

Acknowledgments: The authors give appreciations for the help of Menghsiao Meng, in grammar writing. We would like give thanks for the suggestions and comments from the reviewers and the editors.

Conflicts of Interest: The authors declare no conflict of interest.

\section{References}

1. Tardif-Douglin, D.G. The Marketing of Sweet Potatoes in Rwanda: Commercializing A Perishable Crop under Adverse Conditions. Ph.D. Thesis, Cornell University, New York, NY, USA, 1994.

2. Goda, Y.; Shimizu, T.; Kato, Y.; Nakamura, M.; Maitani, T.; Yamada, T.; Terahara, N.; Yamaguchi, M. Two acylated anthocyanins from purple sweet potato. Phytochemistry 1997, 44, 183-186. [CrossRef]

3. GuiLing, L.; HaiXia, L.; Binhui, G.; Peng, Z. Effects of Different Extraction Methods on Anthocyanin Content Detection in Sweet Potato. Chin. Agric. Sci. Bull. 2007, 23, 91-94. 
4. Huang, Y.-C.; Chang, Y.-H.; Shao, Y.-Y. Effects of genotype and treatment on the antioxidant activity of sweet potato in Taiwan. Food Chem. 2006, 98, 529-538. [CrossRef]

5. Chou, C.; Li, M. A research of effect of three sweet potato varieties and addition on resistant starch content and physical characteristics of steamed rice bowl cake. J. Food Nutr. Res. 2018, 6, 551-556. [CrossRef]

6. Mu, T.H.; Sun, H.N.; Li, P.G. Other sweet potato-based products. Trop. Roots Tubers 2016, 11, 532-557.

7. Low, J.W.; van Jaarsveld, P.J. The potential contribution of bread buns fortified with $\beta$-carotene-rich sweet potato in Central Mozambique. Food Nutr. Bull. 2008, 29, 98-107. [CrossRef]

8. Kano, M.; Takayanagi, T.; Harada, K.; Makino, K.; Ishikawa, F. Antioxidative activity of anthocyanins from purple sweet potato, Ipomoera batatas cultivar Ayamurasaki. Biosci. Biotechnol. Biochem. 2005, 69, 979-988. [CrossRef]

9. Ahmed, M.; Akter, M.S.; Eun, J.-B. Optimization conditions for anthocyanin and phenolic content extraction form purple sweet potato using response surface methodology. Int. J. Food Sci. Nutr. 2011, 62, 91-96. [CrossRef]

10. Fan, G.; Han, Y.; Gu, Z.; Chen, D. Optimizing conditions for anthocyanins extraction from purple sweet potato using response surface methodology (RSM). Food Sci. Technol. 2008, 41, 155-160. [CrossRef]

11. Yoshimoto, M.; Okuno, S.; Yamaguchi, M.; Yamakawa, O. Antimutagenicity of deacylated anthocyanins in purple-fleshed sweetpotato. Biosci. Biotechnol. Biochem. 2001, 65, 1652-1655. [CrossRef]

12. Gansch, H.; Weber, C.A.; Lee, C.Y. Antioxidant Capacity and Phenolic Phytochemicals in Black Raspberries. Red 2009, 17, 20-23.

13. Sutharut, J.; Sudarat, J. Total anthocyanin content and antioxidant activity of germinated colored rice. Int. Food Res. J. 2012, 19, 215-221.

14. Khanal, R.C.; Howard, L.R.; Prior, R.L. Effect of heating on the stability of grape and blueberry pomace procyanidins and total anthocyanins. Food Res. Int. 2010, 43, 1464-1469. [CrossRef]

15. Tsuda, T.; Horio, F.; Uchida, K.; Aoki, H.; Osawa, T. Dietary cyanidin 3-O- $\beta$-D-glucoside-rich purple corn color prevents obesity and ameliorates hyperglycemia in mice. J. Nutr. 2003, 133, 2125-2130. [CrossRef]

16. Mozaffari-Khosravi, H.; Jalali-Khanabadi, B.-A.; Afkhami-Ardekani, M.; Fatehi, F. Effects of sour tea (Hibiscus sabdariffa) on lipid profile and lipoproteins in patients with type II diabetes. J. Altern. Complementary Med. 2009, 15, 899-903. [CrossRef]

17. Yang, M.-Y.; Peng, C.-H.; Chan, K.-C.; Yang, Y.-S.; Huang, C.-N.; Wang, C.-J. The hypolipidemic effect of Hibiscus sabdariffa polyphenols via inhibiting lipogenesis and promoting hepatic lipid clearance. J. Agric. food Chem. 2009, 58, 850-859. [CrossRef]

18. Kong, J.-M.; Chia, L.-S.; Goh, N.-K.; Chia, T.-F.; Brouillard, R. Analysis and biological activities of anthocyanins. Phytochemistry 2003, 64, 923-933. [CrossRef]

19. Hughes, L. Biological consequences of global warming: Is the signal already apparent? Trends Ecol. Evol. 2000, 15, 56-61. [CrossRef]

20. Lustig, R.H.; Schmidt, L.A.; Brindis, C.D. Public health: The toxic truth about sugar. Nature 2012, 482, 27-29. [CrossRef]

21. Hawkes, C. The worldwide battle against soft drinks in schools. Am. J. Prev. Med. 2010, 38, 457-461. [CrossRef]

22. Charters, S.; Velikova, N.; Ritchie, C.; Fountain, J.; Thach, L.; Dodd, T.H.; Fish, N.; Herbst, F.; Terblanche, N. Generation $Y$ and sparkling wines: A cross-cultural perspective. Int. J. Wine Bus. Res. 2011, 23, 161-175. [CrossRef]

23. Ferrier, C. Bottled water: Understanding a social phenomenon. AMBIO J. Hum. Environ. 2001, 30, 118-120. [CrossRef]

24. Santoiemmo, C. Select Serving and Flavored Sparkling Beverage Maker. U.S. Patent No. 8,250,972, 28 August 2012.

25. Viljanen, K.; Kylli, P.; Hubbermann, E.-M.; Schwarz, K.; Heinonen, M. Anthocyanin antioxidant activity and partition behavior in whey protein emulsion. J. Agric. Food Chem. 2005, 53, 2022-2027. [CrossRef]

26. Abdel-Aal, E.-S.M.; Young, J.C.; Rabalski, I. Anthocyanin composition in black, blue, pink, purple, and red cereal grains. J. Agric. food Chem. 2006, 54, 4696-4704. [CrossRef]

27. Geissman, T. Anthocyanins, chalcones, aurones, flavones and related water-soluble plant pigments. In Moderne Methoden der Pflanzenanalyse/Modern Methods of Plant Analysis; Springer: Berlin, Germany, 1955; pp. 450-498. 
28. Martynenko, A.; Chen, Y. Degradation kinetics of total anthocyanins and formation of polymeric color in blueberry hydrothermodynamic (HTD) processing. J. Food Eng. 2016, 171, 44-51. [CrossRef]

29. Khoo, H.E.; Azlan, A.; Tang, S.T.; Lim, S.M. Anthocyanidins and anthocyanins: colored pigments as food, pharmaceutical ingredients, and the potential health benefits. Food Nutr. Res. 2017, 61, 779. [CrossRef]

30. Sui, X. Changes in the color, chemical stability and antioxidant capacity of thermally treated anthocyanin aqueous solution over storage. In Impact of Food Processing on Anthocyanins; Springer: Singapore, 2017; pp. 49-65.

31. Weber, F.; Boch, K.; Schieber, A. Influence of copigmentation on the stability of spray dried anthocyanins from blackberry. LWT-Food Sci. Technol. 2017, 75, 72-77. [CrossRef]

32. Giusti, M.M.; Wrolstad, R.E. Characterization and measurement of anthocyanins by UV-visible spectroscopy. Curr. Protoc. Food Anal. Chem. 2001, F1.2.1-F1.2.13. [CrossRef]

33. Brand-Williams, W.; Cuvelier, M.-E.; Berset, C. Use of a free radical method to evaluate antioxidant activity. LWT-Food Sci. Technol. 1995, 28, 25-30. [CrossRef]

34. Li, H.; Wang, X.; Li, P.; Li, Y.; Wang, H. Comparative study of antioxidant activity of grape (Vitis vinifera) seed powder assessed by different methods. J. Food Drug Anal. 2008, 16, 67-73.

35. Wahyuningsih, S.; Wulandari, L.; Wartono, M.; Munawaroh, H.; Ramelan, A. The effect of $\mathrm{pH}$ and color stability of anthocyanin on food colorant. In Proceedings of the IOP Conference Series: Materials Science and Engineering, Surakarta, Indonesia, October 2016; p. 012047.

36. Wu, H.-Y.; Yang, K.-M.; Chiang, P.-Y. Roselle anthocyanins: Antioxidant properties and stability to heat and pH. Molecules 2018, 23, 1357. [CrossRef]

37. Heinonen, J.; Farahmandazad, H.; Vuorinen, A.; Kallio, H.; Yang, B.; Sainio, T. Extraction and purification of anthocyanins from purple-fleshed potato. Food Bioprod. Process. 2016, 99, 136-146. [CrossRef]

38. Huang, H.; Xu, Q.; Belwal, T.; Li, L.; Aalim, H.; Wu, Q.; Duan, Z.; Zhang, X.; Luo, Z. Ultrasonic impact on viscosity and extraction efficiency of polyethylene glycol: A greener approach for anthocyanins recovery from purple sweet potato. Food Chem. 2019, 283, 59-67. [CrossRef]

39. Liu, X.; Mu, T.; Sun, H.; Zhang, M.; Chen, J. Optimisation of aqueous two-phase extraction of anthocyanins from purple sweet potatoes by response surface methodology. Food Chem. 2013, 141, 3034-3041. [CrossRef]

40. Li, J.; Li, X.-D.; Zhang, Y.; Zheng, Z.-D.; Qu, Z.-Y.; Liu, M.; Zhu, S.-H.; Liu, S.; Wang, M.; Qu, L. Identification and thermal stability of purple-fleshed sweet potato anthocyanins in aqueous solutions with various $\mathrm{pH}$ values and fruit juices. Food Chem. 2013, 136, 1429-1434. [CrossRef]

41. Ghosh, D.; Konishi, T. Anthocyanins and anthocyanin-rich extracts: role in diabetes and eye function. Asia Pac. J. Clin. Nutr. 2007, 16, 200-208.

42. Tsuda, T.; Shiga, K.; Ohshima, K.; Kawakishi, S.; Osawa, T. Inhibition of lipid peroxidation and the active oxygen radical scavenging effect of anthocyanin pigments isolated from Phaseolus vulgaris L. Biochem. Pharmacol. 1996, 52, 1033-1039. [CrossRef]

43. Hagiwara, A.; Yoshino, H.; Ichihara, T.; Kawabe, M.; Tamano, S.; Aoki, H.; Koda, T.; Nakamura, M.; Imaida, K.; Ito, N. Prevention by natural food anthocyanins, purple sweet potato color and red cabbage color, of 2-amino-1-methyl-6-phenylimidazo (4,5-B) pyridine (phip)-associated colorectal carcinogenesis in rats. J. Toxicol. Sci. 2002, 27, 57-68. [CrossRef]

44. Wang, S.; Chu, Z.; Ren, M.; Jia, R.; Zhao, C.; Fei, D.; Su, H.; Fan, X.; Zhang, X.; Li, Y. Identification of anthocyanin composition and functional analysis of an anthocyanin activator in solanum nigrum fruits. Molecules 2017, 22, 876. [CrossRef]

45. Thaipong, K.; Boonprakob, U.; Crosby, K.; Cisneros-Zevallos, L.; Byrne, D.H. Comparison of ABTS, DPPH, FRAP, and ORAC assays for estimating antioxidant activity from guava fruit extracts. J. Food Compos. Anal. 2006, 19, 669-675. [CrossRef]

46. Seo, W.D.; Kim, J.Y.; Han, S.-I.; Ra, J.-E.; Lee, J.H.; Song, Y.C.; Park, M.J.; Kang, H.W.; Oh, S.K.; Jang, K.C. Relationship of radical scavenging activities and anthocyanin contents in the 12 colored rice varieties in Korea. J. Korean Soc. Appl. Biol. Chem. 2011, 54, 693-699. [CrossRef]

47. Ferretti, G.; Neri, D.; Bacchetti, T. Effect of Italian sour cherry (Prunus cerasus L.) On the formation of advanced glycation end products and lipid peroxidation. Food Nutr. Sci. 2014, 5, 1568-1576.

48. Lee, H.-R.; Hwang, I.-W.; Zheng, H.-Z.; Jeong, W.-S.; Kim, Y.-C.; Chung, S.-K. Antioxidant properties of proanthocyanidin fraction isolated from wild grape (Vitis amurensis) peel. Korean J. Food Sci. Technol. 2010, 42, 420-423. 
49. Strugala, P.; Dudra, A.; Kucharska, A.Z.; Sokół-Łętowska, A.; Wojnicz, D.; Cisowska, A.; Walkowski, S.; Sroka, Z.; Gabrielska, J.; Hendrich, A.B. Biological activity of the methanol and water extracts of the fruits of anthocyanin-rich plants grown in south-west Poland. Nat. Prod. Commun. 2015, 10, 467-474. [CrossRef]

50. De Moura, S.C.; Berling, C.L.; Germer, S.P.; Alvim, I.D.; Hubinger, M.D. Encapsulating anthocyanins from Hibiscus sabdariffa L. calyces by ionic gelation: Pigment stability during storage of microparticles. Food Chem. 2018, 241, 317-327. [CrossRef]

51. Kechinski, C.P.; Guimarães, P.V.R.; Noreña, C.P.Z.; Tessaro, I.C.; Marczak, L.D.F. Degradation kinetics of anthocyanin in blueberry juice during thermal treatment. J. Food Sci. 2010, 75, C173-C176. [CrossRef]

52. Askar, K.A.; Alsawad, Z.H.; Khalaf, M.N. Evaluation of the $\mathrm{pH}$ and thermal stabilities of rosella anthocyanin extracts under solar light. Beni-Suef Univ. J. Appl. Sci. 2015, 4, 262-268. [CrossRef]

53. Özkan, M.; Yemenicioğlu, A.; Cemeroğlu, B. Degradation of various fruit juice anthocyanins by hydrogen peroxide. Food Res. Int. 2005, 38, 1015-1021. [CrossRef]

54. Furtado, P.; Figueiredo, P.; das Neves, H.C.; Pina, F. Photochemical and thermal degradation of anthocyanidins. J. Photochem. Photobiol. A. Chem. 1993, 75, 113-118. [CrossRef]

55. Zhao, M.; Luo, Y.; Li, Y.; Liu, X.; Wu, J.; Liao, X.; Chen, F. The identification of degradation products and degradation pathway of malvidin-3-glucoside and malvidin-3,5-diglucoside under microwave treatment. Food Chem. 2013, 141, 3260-3267. [CrossRef]

56. Achir, N.; Sinela, A.; Mertz, C.; Fulcrand, H.; Dornier, M. Monitoring anthocyanin degradation in Hibiscus sabdariffa extracts with multi-curve resolution on spectral measurement during storage. Food Chem. 2019, 271, 536-542. [CrossRef]

57. Zhang, Z.; Li, J.; Fan, L. Evaluation of the composition of Chinese bayberry wine and its effects on the color changes during storage. Food Chem. 2019, 276, 451-457. [CrossRef]

58. Panić, M.; Gunjević, V.; Cravotto, G.; Redovniković, I.R. Enabling technologies for the extraction of grape-pomace anthocyanins using natural deep eutectic solvents in up-to-half-litre batches Extraction of grape-pomace anthocyanins using NADES. Food Chem. 2019, 300, 125185. [CrossRef]

(C) 2019 by the authors. Licensee MDPI, Basel, Switzerland. This article is an open access article distributed under the terms and conditions of the Creative Commons Attribution (CC BY) license (http://creativecommons.org/licenses/by/4.0/). 